\title{
ALOE VERA LINN GEL DAN GULA DARAH PUASA PADA KLIEN PREDIABETES
}

\section{ALOE VERA LINN GEL AND FASTING BLOOD SUGAR IN PREDIABETES CLIENTS}

\author{
Evelin Malinti ${ }^{1}$, Susy A. Jael ${ }^{2}$ \\ Fakultas IImu Keperawatab, Universitas Advent Indonesia ${ }^{1}$, College of Nursing, Adventist \\ University of the Philippines ${ }^{2}$ \\ E-mail: evelinmalinti@yahoo.com
}

\begin{abstract}
Abstrak
Pendahuluan: Aloe Vera Linn, umumnya dikenal sebagai Aloe Vera telah menarik perhatian dunia karena khasiat pengobatnya yang efektif bagi banyak masalah kesehatan termasuk hiperglikemia. Tujuan: Secara khusus, penelitian ini bertujuan untuk menilai efektivitasnya pada klien prediabetes dalam dua kelompok eksperimen yang berbeda, sebelum dan setelah tujuh hari perawatan yang mendokumentasikan perubahan pada kadar glukosa darah puasa klien. Metode: Penelitian ini menggunakan desain eksperimen semu. Pengambilan sampel purposive digunakan untuk memastikan bahwa para peserta memenuhi kriteria penelitian dan dilakukan pengacakan dengan cara pengundian dalam membagi peserta menjadi dua kelompok eksperimen dengan 15 peserta untuk setiap kelompok. Hasil: Penelitian ini membandingkan dua kelompok eksperimen: kelompok pertama yang diterapi dengan $100 \mathrm{~g}$ Aloe Vera gel per hari, dan kelompok kedua yang diterapi dengan $200 \mathrm{~g}$ Aloe Vera per hari selama tujuh hari. terapi gel Aloe Vera $100 \mathrm{~g}$ dan $200 \mathrm{~g}$ efektif dalam menurunkan kadar glukosa darah puasa para partisipan. Tercatat bahwa, gel Aloe Vera $200 \mathrm{~g}$ memberikan penurunan signifikan lebih tinggi dari kadar glukosa darah puasa dibandingkan dengan $100 \mathrm{~g}$ Aloe Vera gel. Diskusi: Oleh karena itu, penelitian menunjukkan bahwa gel Aloe Vera efisien sebagai terapi unatuk menurunkan kadar glukosa darah di antara klien prediabetes.
\end{abstract}

Kata kunci: Gel Llidah Buaya, Glukosa Darah, Prediabetes

\begin{abstract}
Introduction: Aloe Vera Linn, commonly known as Aloe Vera, has caught the world's attention due to its effective medicinal properties for many health problems including hyperglycemia. . Purpose: In particular, this study aimed to assess its effectiveness on prediabetes clients in two different experimental groups, before and after seven days of treatment that documented changes in the client's fasting blood glucose levels. Method: This study utilized quasiexperimental design. Purposive sampling was used to ensure that participants met the research criteria in which randomization by casting lots was employed in dividing participants into two experimental groups with 15 participants for each group. Results: The study compared two experimental groups: the first group treated with $100 \mathrm{~g}$ of Aloe Vera gel per day, and the second group treated with $200 \mathrm{~g}$ of Aloe Vera per day for seven days. The therapy of Aloe Vera gel $100 \mathrm{~g}$ and $200 \mathrm{~g}$ was effective in reducing fasting blood glucose levels of the participants. Notedly; Aloe Vera gel $200 \mathrm{~g}$ provides a higher significant reduction of fasting blood glucose levels compared to $100 \mathrm{~g}$ of Aloe Vera gel. Discussion: Therefore, research shows that Aloe Vera gel is efficient as a treatment for reducing blood glucose levels among prediabetes clients.
\end{abstract}

Keywords: Aloe Vera Linn Gel, Blood Glucose, Prediabetes

JURNAL

SKOLASTIK

KEPERAWATAN

Vol, 5, No. 1

Januari - Juni 2019

ISSN: $2443-0935$

E-ISSN $2443-16990$ 


\section{PENDAHULUAN}

Diabetes adalah "silent disease" di mana tanda dari kondisi ini tidak selalu dramatis; bahkan mungkin tidak terlihat (Heggs, 2013; American Diabetes Association, 2009). Diabetes tidak lagi dianggap sebagai penyakit orang kaya, tetapi telah menjadi masalah dimasyarakat bahkan populasi ekonomi rendah melebihi penyakit menular. Pria dan wanita, yang terjebak oleh stigma, kemiskinan, dan kesalahan informasi, seringkali tidak mencari pertolongan untuk diabetes pada awalnya sampai tahap lanjut atau dengan komplikasi. Gagal ginjal, penyakit kardiovaskular, dan kebutaan adalah komplikasi umum dari diabetes (Murphy, 2013).

Pada tahun 2011, IDF Global Diabetes Plan 2011-2021 diluncurkan, di mana dua tujuannya adalah untuk meningkatkan hasil kesehatan diabetisi dan mencegah perkembangan diabetes tipe 2. Diagnosis dini, pengobatan yang efektif biaya, dan edukasi manajemen diri dapat mencegah atau secara signifikan menunda komplikasi terkait diabetes yang merusak dan menyelamatkan nyawa.

Obat tradisional adalah salah satu cara paling pasti untuk mencapai cakupan perawatan kesehatan total dari populasi dunia (Kumar, Shukla, \& Rao, 2011). Alasan paling umum untuk menggunakan obat tradisional adalah harganya lebih terjangkau, dan lebih dekat dengan ideologi pasien (Benzie \& Wachtel-Galor, 2011). Aloe Vera adalah tanaman obat tertua yang pernah dikenal dan tanaman obat paling banyak digunakan di seluruh dunia. Ini dapat mengatasi berbagai penyakit termasuk diabetes (Rajeswari, Umadevi, Rahale, Pushpa, Selvavenkadesh, Sampath-Kumar, \& Bhowmik, 2012).

Menurut Hamman (2008), Aloe Vera menghasilkan efek anti-diabetes yang dapat membantu menurunkan kadar glukosa darah dengan meningkatkan metabolisme glukosa. Lebih lanjut, seperti yang disebutkan oleh Surjushe, Vasani, dan Saple (2008) komponen enzim Aloe Vera membantu dalam pemecahan gula dan lemak.

Efek obat dari ekstrak Aloe Vera telah dikaitkan dengan tindakan sinergis phytochemical-nya (Hamman, 2008), seperti glukomanan, acemannan, saponin dan lainnya yang memiliki efek antioksidan potensial (Sharrif \& Verma, 2011). Selain itu sebagaimana dikutip oleh Singh, Singh, Rani, dan Maheshwari (2011), polisakarida dalam gel Aloe Vera memiliki sifat terapeutik yang mencakup efek antidiabetes dan antioksidan. Sood, Baker, dan Coleman (2008) menyimpulkan dalam penelitian mereka bahwa glukomanan tampaknya secara menguntungkan mempengaruhi kolesterol total, kolesterol-lipoprotein kepadatan rendah, trigliserida, berat badan, dan glukosa darah puasa.

Selanjutnya, hasil skrining fitokimia Aloe Vera dari Toklas Center, MMSU menunjukkan bahwa fotokimia Aloe Vera meliputi: flavonoid, kumarin, xanthoprotein, saponin, dan terpenoid.. Fitokimia ini menimbulkan aktivitas antioksidan, yang memainkan peran penting sebagai faktor pelindung terhadap penyakit terkait stres oksidatif 
(Preedy, 2014). Aktivitas antioksidan phytochemical ini efektif dalam menurunkan kadar glukosa darah dengan meningkatkan sekresi insulin; mengurangi resistensi insulin dan stres oksidatif; mengatur metabolisme glukosa dalam hepatosit; dan peningkatan penyerapan glukosa pada otot rangka dan jaringan adiposa (Babu, Liu, \& Gilbert, 2013; Bubols et al., 2013; Gato, Takahasi, Hirai, \& Kawada, 2010; Kharwal et al., 2012)

\section{METODE}

Penelitian ini menggunakan eksperimen semu dengan desain penelitian pre dan post-test. Variabel bebas yaitu gel Aloe Vera dibagi menjadi dua: $200 \mathrm{~g} / \mathrm{hari}$ dan $100 \mathrm{~g} /$ hari. Ini digunakan untuk menguji keefektifannya sebagai terapi pada pradiabetes khusus untuk glukosa darah puasa.

Penelitian ini dilakukan pada populasi di Bawoleu, Kecamatan Tagulandang Utara-Indonesia. Sebanyak 107 calon peserta dengan usia mulai 30-60 tahun yang memiliki faktor risiko prediabetes berdasarkan wawancara datang, mendaftar dan menandatangani persetujuan untuk tes skrining. Hanya 56 peserta yang memenuhi kriteria glukosa darah puasa dan 32 menandatangani persetujuan untuk berpartisipasi dalam tujuh (7) hari terapi gel Aloe Vera. Para peserta ini didistribusikan secara merata dalam dua kelompok: $100 \mathrm{~g}$ dan $200 \mathrm{~g}$ dosis gel Aloe Vera.Para peserta ini didistribusikan secara merata dalam dua kelompok: $100 \mathrm{~g}$ dan $200 \mathrm{~g}$ dosis gel Aloe Vera. Teknik pengambilan sampel acak sederhana digunakan dalam menugaskan peserta untuk kelompok tertentu. Dua peserta mengundurkan diri selama proses perawatan. Satu karena mual dan satunya lagi karena migrasi ke tempat lain.

\section{Persiapan lidah buaya}

Aloe Vera yang digunakan dalam penelitian ini telah menjalani skrining fitokimia di Pusat Penelitian Toklas di Universitas Negeri Mariano Marcos (MMSU) di Filipina. Proses penyaringan fitokimia termasuk mengekstraksi Aloe Vera dengan air dan $70 \%$ etanol untuk flavonoid, kumarin, xanthoprotein, saponin, terpenoid, alkaloid, tanin, dan steroid.

Persiapan gel Aloe Vera dilakukan oleh peneliti dan 1 asisten di pagi dan sore hari. Langkah-langkah persiapan gel Aloe Vera:

1. Daun lidah buaya segar (Aloe Vera L.) dipilih dan dicuci.

2. Kulit hijau daun Aloe Vera dikupas untuk mendapatkan gel bagian dalam.

3. Gel Aloe Vera dicuci tiga kali dengan air bersih untuk menghilangkan getah kuning.

4. Gel Aloe Vera yang dicuci dan dipotong dalam bentuk kubus dengan ukuran $2 \mathrm{~cm}$ panjang menggunakan pisau stainless dan talenan.

5. Gel Aloe Vera ditimbang dan dikemas dalam gelas. Setiap Paket mengandung $100 \mathrm{~g}$ gel Aloe Vera.

\section{Terapi gel Aloe vera}

Prosedur terapi Aloe Vera adalah sebagai berikut: 
1. Setiap peserta dalam kedua kelompok menerima satu paket $(100 \mathrm{~g})$ gel Aloe Vera dan 1 sachet (1 g) pemanis nol kalori di pagi hari sebelum sarapan.

2. Para peserta di kedua kelompok memakan gel Aloe Vera yang dicampur dengan pemanis nol kalori

3. Para peserta dalam kelompok dosis 200 g menerima 100 g Aloe Vera paket lainnya dengan 1 sachet $(1 \mathrm{~g})$ pemanis nol kalori di malam hari sebelum makan malam.

4. Langkah nomor 1 hingga 3 diulang setiap hari selama tujuh hari.

5. Pada hari ketujuh, peserta diinstruksikan puasa selama 10 jam untuk menjalani post test puasa glukosa darah.

\section{Pengukuran glukosa darah puasa}

Dua hari sebelum terapi gel Aloe Vera, para peserta diinstruksikan untuk berpuasa selama 10 jam mulai dari jam 9 malam hingga jam 7 pagi. Setelah 10 jam puasa, peserta diminta datang ke pusat kesehatan untuk tes darah. Hasil tes darah adalah hasil pre test untuk glukosa darah. Untuk mengukur glukosa darah puasa pasca terapi, para peserta di kedua kelompok pada hari ketujuh terapi gel Aloe Vera diinstruksikan untuk berpuasa untuk prosedur tes darah.

\section{HASIL DAN DISKUSI}

Sebanyak 30 peserta mampu menyelesaikan prosedur terapi. Sebelum intervensi, peserta $(n=15)$ dalam dosis $100 \mathrm{~g}$ memiliki rata-rata 107,73 (SD = 6,76) untuk glukosa darah puasa mereka, yang termasuk kategori batas tinggi. Di sisi lain, para peserta dalam kelompok $200 \mathrm{~g}$ dosis gel Aloe Vera $(\mathrm{n}=15)$ memiliki rata-rata $108,53(\mathrm{SD}=7,39)$ untuk glukosa darah puasa mereka sebelum perawatan, yang diberi label batas tinggi. Perbedaan glukosa darah puasa antar kelompok adalah $\mathrm{t}=.310, \mathrm{p}=$ $.759, \mathrm{~d}=.170$ (tabel 1). Hasilnya mengungkapkan bahwa tidak ada perbedaan yang signifikan dalam hasil pra-perawatan glukosa darah puasa. Ini menyiratkan bahwa dalam kedua kelompok sebanding.

Table 1. Perbedaan rata-rata glukosa darah puasa sebelum terapi

\begin{tabular}{lllllll}
\hline $\begin{array}{l}\text { Gro } \\
\text { up }\end{array}$ & N & $\begin{array}{l}\text { Mea } \\
\mathrm{n}\end{array}$ & SD & $t$ & $p$ & $\mathrm{~d}$ \\
\hline 100 & 1 & 107. & 6.7 & .31 & .75 & .17 \\
$\mathrm{~g}$ & 5 & 73 & 6 & 0 & 9 & 0 \\
\hline 200 & 1 & 108. & 7.3 & & & \\
$\mathrm{~g}$ & 5 & 53 & 9 & & & \\
\hline
\end{tabular}

Hasil pasca terapi menunjukkan penurunan rata-rata glukosa darah puasa. Dalam kelompok $100 \mathrm{~g}$ Aloe Vera gel FBG menjadi 97,33 (SD = 6,01 ) dengan $\mathrm{t}=8,565, \mathrm{p}=.000, \mathrm{~d}=$ 2,36. Sedangkan untuk kelompok 200,0 g Aloe Vera gel FBG menjadi 92,07 $(\mathrm{SD}=5,32)$ dengan $\mathrm{t}=8,995, \mathrm{p}=.000$, $\mathrm{d}=2,32$ (tabel 2). Hasil ini menunjukkan bahwa ada perbedaan yang signifikan dengan ukuran efek yang besar antara hasil glukosa darah puasa sebelum dan sesudah terapi pada kelompok perlakuan $100 \mathrm{~g}$ dan $200 \mathrm{~g}$. 
Table 2. Perbedaan rata-rata glukosa darah puasa sebelum dan sesudah terapi

\begin{tabular}{lllllll}
\hline $\begin{array}{l}\text { Gro } \\
\text { up }\end{array}$ & & $\begin{array}{l}\text { Mea } \\
\mathrm{n}\end{array}$ & $\begin{array}{l}\mathrm{S} \\
\mathrm{D}\end{array}$ & $t$ & $p$ & $\mathrm{~d}$ \\
\hline 100 & $\mathrm{pr}$ & 107. & 6. & 8.5 & .0 & 2. \\
$\mathrm{~g}$ & $\mathrm{e}$ & 73 & 76 & 65 & 00 & 36 \\
& $\mathrm{po}$ & 97.3 & 6. & & & \\
& $\mathrm{st}$ & 3 & 01 & & & \\
\hline 200 & pr & 108. & 7. & 8.9 & .0 & 2. \\
$\mathrm{~g}$ & $\mathrm{e}$ & 53 & 39 & 95 & 00 & 32 \\
& po & 92.0 & 5. & & & \\
& st & 7 & 32 & & & \\
& & & & & & \\
\hline
\end{tabular}

Data pada tabel diatas menyiratkan bahwa $100 \mathrm{~g}$ dan $200 \mathrm{~g}$ perawatan gel Aloe Vera selama 7 hari efektif dalam menurunkan glukosa darah puasa. Menurut Cowsert (2010), acemannan dalam gel Aloe Vera terkait dengan sintesis dan pelepasan insulin oleh mannose-nya yang memiliki peran penting dalam komunikasi sel ke sel. Glucomannan, polisakarida lain dalam gel Aloe Vera memiliki kemampuan untuk merangsang sekresi insulin dan sensitivitas insulin selanjutnya mengurangi kadar glukosa darah (Bagchi \& Preuss, 2013). Fitokimia lain seperti flavonoid, kumarin, saponin, dan terpenoid yang memiliki aktivitas antioksidan juga bekerja dalam mengurangi kolesterol darah dan kadar glukosa darah. Efek antidiabetes Aloe Vera diselidiki pada tikus diabetes yang diinduksi aloksan selama 30 hari dengan dosis oral $150 \mathrm{mg} / \mathrm{kg}$ berat badan. Setelah perawatan, glukosa darah puasa menunjukkan penurunan yang signifikan (Rehman, Jafri, Hassan, Ahmed, \& Naim, 2011). Pemberian gel Aloe Vera olahan pada tikus diabetes yang diinduksi diet menunjukkan penurunan resistensi insulin (Kim, Kim, Kwon, Lee, Kong, Im, Lee, et al., 2009).

Penelitian sebelumnya pada klien oleh Sari (2010) yang mengevaluasi 10 hari rebusan Aloe Vera gel pada pasien diabetes tipe 2 dan Choi, et al., (2012) menggunakan Aloe Vera dengan kapsul pada pasien prediabetik dan diabetes awal dalam empat minggu memberikan penurunan yang signifikan pada hasil glukosa darah puasa. Penelitian lain menggunakan fraksi berat molekul tinggi Aloe Vera pada pasien diabetes tipe 2 menunjukkan penurunan glukosa darah setelah enam minggu terapi (Yagi, Hegazy, Kabbash, \& Wahab, 2009). Selain itu, Fallah, et al. (2012) mengobati klien diabetes tipe 2 yang membutuhkan insulin dengan 300 mg kapsul Aloe Vera dua (2) kali sehari selama dua (2) bulan, sebagai hasilnya ada penurunan yang signifikan dalam glukosa darah dan hemoglobin terglikosilasi.

Studi ini juga menunjukkan pada tabel 3 bahwa skor pencapaian rata-rata glukosa darah puasa dari mereka yang menerima $100 \mathrm{~g}$ Aloe Vera adalah 10,40 (SD = 4,70), dan mereka yang menerima 200 g Aloe Vera gel memiliki skor pencapaian rata-rata $16,47(\mathrm{SD}=7.09)$ dengan $\mathrm{t}=-2.762, \mathrm{p}$ $=.011, \mathrm{~d}=1.008$. Penurunan glukosa darah puasa lebih tinggi untuk kelompok mereka yang menerima 200 g Aloe Vera dibandingkan dengan kelompok yang menerima $100 \mathrm{~g}$ Aloe Vera gel. Perbedaan skor pencapaian signifikan pada tingkat $0,05(\mathrm{p}=0,011)$ dengan ukuran efek besar $(\mathrm{d}=1,008)$ 
Table 3. Perbedaan rata-rata skor pencapaian penurunan glukosa darah puasa

\begin{tabular}{lllllll}
\hline & $\mathrm{N}$ & $\begin{array}{l}\text { Me } \\
\text { Grou }\end{array}$ & S & $t$ & $p$ & $\mathrm{~d}$ \\
$\mathrm{p}$ & & $\begin{array}{l}\text { an } \\
\text { of } \\
\text { gai }\end{array}$ & & & & \\
& & & & & \\
& & & & & & \\
& & sco & & & & \\
& & re & & & & \\
\hline & 1 & 10. & 4. & - & .0 & 1.0 \\
100 & 5 & 40 & 70 & 2.7 & 11 & 08 \\
$\mathrm{~g}$ & & & & 62 & & \\
& 1 & 16. & 7. & & & \\
200 & 5 & 47 & 09 & & & \\
$\mathrm{~g}$ & & & & & & \\
\hline
\end{tabular}

Oleh karena itu dipandang bahwa ada perbedaan yang signifikan dengan ukuran efek besar dalam skor pencapaian glukosa darah puasa antara mereka yang menerima $100 \mathrm{~g}$ gel lidah buaya dan mereka yang menerima 200 g gel lidah buaya. Hasilnya menyiratkan bahwa semakin tinggi dosis gel Aloe Vera, semakin besar penurunan kadar glukosa darah puasa. Semakin tinggi dosis gel Aloe Vera semakin efektif menurunkan kadar glukosa darah.

Hasil penelitian ini konsisten dengan penelitian yang dilakukan oleh Sharma, Siddiqui, Ram, Chaudhary, dan Sharma (2013) yang mengungkapkan bahwa semakin tinggi dosis Aloe Vera semakin besar pula penurunan kadar glukosa darah puasa. Mereka membandingkan secara oral $300 \mathrm{mg}$ dan $500 \mathrm{mg}$ Aloe Vera gel / kg berat badan tikus diabetes selama 21 hari pengobatan. Dosis lima ratus miligram memiliki pengurangan glukosa darah yang lebih tinggi dibandingkan dengan dosis $300 \mathrm{mg}$.

Studi lain membandingkan 150 dan 300 mg ekstrak lidah buaya / kg berat badan tikus diabetes mengungkapkan bahwa Aloe Vera $(150 \mathrm{mg})$ tidak membuat perubahan pada rata-rata glukosa plasma hewan. Sedangkan, Aloe Vera (300 mg) secara signifikan mengurangi rata-rata kadar glukosa plasma (Mohapatra, Rath, Maharana, Pradhan, \& Tripathy, 2013). Penelitian terdahulu lainnya (Choi, et al., 2012; Fallah, et al., 2012; Pertiwi \& Murwarni, 2012; \& Rehman, et al., 2011) yang menggunakan dosis tunggal Aloe Vera yang berbeda untuk mengevaluasi perbedaan dalam darah puasa Tingkat glukosa setelah perawatan, semua membuktikan keefektifan gel Aloe Vera dalam menurunkan glukosa darah.

\section{KESIMPULAN}

Berdasarkan temuan, disimpulkan bahwa terapi tujuh (7) hari gel Aloe Vera baik dosis $100 \mathrm{~g}$ atau $200 \mathrm{~g}$, efektif dalam menurunkan kadar glukosa darah puasa di antara klien prediabetes. Lebih lanjut, semakin tinggi dosis gel Aloe Vera, semakin besar pula penurunan glukosa darah puasa.

\section{DAFTAR PUSTAKA}

American Diabetes Association. (2009). Toolkit 1: All about your risk for pre-diabetes, type 2 diabetes, and heart disease. Retrieved from http://professional.diabetes. org/admin/UserFiles/2014\%20CM R\%20English/All\%20About\%20Pr 
ediabetes\%20T2D\%20and\%20Hea rt\%20Disease.pdf

Babu, P. V., Liu, D., \& Gilbert, R. E. (2013). Recent advances in understanding the anti-diabetic actions of dietary flavonoids. $J$ Nutr Biochem. (2013 Nov). 24(11), 1777-89. doi: 10.1016/j.jnutbio.2013.06.003

Bagchi, D., \& Preuss, H. G. (2013). Obesity: Epidemiology, pathophysiology, and prevention $\left(2^{\text {nd }} \mathrm{ed}\right)$. United States of America: CRC Press Taylor \& Francis Group

Benzie I. F. F., \& Wachtel-Galor, S. (2011). Herbal medicine: Biomolecular and clinical aspects $\left(2^{\text {nd }} \quad\right.$ ed). Retrieved from http://www.ncbi.nlm.nih.gov/book s/ NBK92773/

Bubols, G. B., Vianna, D. R., MedinaRemón, A., von Poser, G., Lamuela-Raventos, L. M., EiflerLima, V. L., \& Garcia, S. C. (2013). The antioxidant activity of coumarins and flavonoids. MiniReviews in Medicinal Chemistry, 13(3), 1-17.

Choi, H., Kim, S., Son, K., Oh, B., \& Cho, B. (2012). Metabolic effects of Aloe Vera gel complex in obese prediabetes and early non-treated diabetic patients: Randomized controlled trial. Nutrition, 29(9), 1110-4. doi: 10.1016/j.nut.2013.02.015

Cowsert, L. M. (2010). Biological activities of acemannan. Retrieved from

http://www.symmetrydirect.com /pdf/BioActivofAcemannan.pdf

Fallah H. H., Kianbakht, S., Hajiaghaee, R., Afkhami-Ardekani M., Bonakdaran, A., \& Hashem, D. F. (2012) Aloe Vera leaf gel in treatment of advanced type 2 diabetes mellitus needing insulin therapy: A randomized doubleblind placebo-controlled clinical trial. Journal of Medicinal Plants, 11(43), 9-27.

Gato, T., Takahashi, N., Hirai, S., \& Kawada, T. (2010). Various terpenoids derived from herbal and dietary plants function as PPAR modulators and regulates carbohydrates and lipid metabolism. Hindawi Publishing Corporation. PPAR Research. Doi:10.1155/2010/483958

Hamman J. H. (2008). Composition and applications of Aloe Vera leaf gel. Molecules, 13, 1599-1616. DOI: 10.3390/molecules13081599

Heggs, D. (2013). Diabetes the silent killer. Retrieved from http://guardianlv.com/2013/07/diab etes-the-silent-killer/

International Diabetes Federation. (2011). Global Diabetes Plan 20112021. Retrieved from http://www.idf.org/sites/default/file s/Global_Diabetes_Plan_Final.pdf Kharwal, H., Panthari, P., Pant, M. K., Kharkwal, H., Kharkwal, A. C., \& Joshi, D. D. (2012). Foaming glycosides: A review. IOSR Journal of Pharmacy, 2(5), 23-28. 
Kim, K., Kim, H., Kwon, J., Lee, S., Kong, H., Im, S. A., Lee, Y. H., Lee, Y. R., Oh, S. T., Jo, T. H., Park, Y. I., Lee, C. K., Kim, K. (2009). Hypoglycemic and hypolipidemic effects of processed Aloe Vera gel in a mouse model of non-insulin-dependent diabetes mellitus. Phytomedicine. Doi:10.1016/j.phymed.2009.02.01 4

Kumar, S., Shukla, G. A., \& Rao, S. A. (2011). The present status of medicinal plants aspects and prospects. Int. J. Res.Pharmac.Biomed.Sci, 2, 22293701 .

Mohapatra, S., Rath, B., Maharana, C. S., Pradhan, S., \& Tripathy, S. (2013). Hypoglycemic, hypolipidemic properties of Aloe Vera in streptozotocin induced diabetic rats. Int $\mathrm{J}$ Biol Med Res, 4(1), 2783-2787.

Murphy, Z. (2013, November). Diabetes: Asia's 'silent killer'. $B B C$ News. Retrieved from http://www.bbc.com/news/world$\underline{\text { asia-24740288 }}$

Pertiwi P.S., \& Murwarni H. (2012). Pengaruh pemberian jus lidah buaya terhadap kadar glukosa darah puasa pada wanita prediabetes. Journal of Nutrition College, 1(1), 179-193

Preedy, V. R. (2014). Diabetes: Oxidative stress and dietary antioxidants. USA: Elsevier
Rajeswari R., Umadevi M., Rahale, C. S., Pushpa, R., Selvavenkadesh, S., Sampath- Kumar, K. P., \& Bhowmik, D. (2012). Aloe Vera: The miracle plant its medicinal and traditional uses in India. Journal of Pharmacognosy and Phytochemistry, 1(4), 118-124.

Rehman, S-U., Jafri, S. A., Hassan, S., Ahmed, I., \& Naim, M. (2011). Study on antidiabetic effect of Aloe Vera extract on alloxan induced diabetic rats. Molecules, 17, 1285112867 , doi:10.3390/molecules171112851

Sari, D. M. (2010). Pemanfaatan lidah buaya (aloe vera) terhadap penurunan kadar gula darah pada penderita diabetes mellitus tipe II di Kecamatan Rantau Selatan Kabupaten Labuhan Batu. Undergraduate Unpublish Thesis. Universitas Sumatra Utara

Sharrif, M. M., \& Verma, S. K. (2011). Aloe Vera their chemicals composition and applications: A review. Int J Biol Med Res, 2(1), 466-471.

Sharma, B., Siddiqui, S., Ram, G., Chaudhary, M., \& Sharma, G. (2013) Hypoglycemic and hepatoprotective effects of processed Aloe Vera gel in a mice model of alloxan induced diabetes mellitus. J Diabetes Metab, 4, 9. Retrieved from http://dx.doi.org/10.4172/2155$\underline{6156.1000303}$

Singh, U., Singh, P., Rani, B., \& Maheshwari, R. (2011). Diverse 
therapeutic applications of aloe vera: A review. International Journal of Pharmaceutical Development \& Technology, 1(1), 25-33.

Sood, N., Baker, W. L., \& Coleman, C. I. (2008). Effect of glucomannan on plasma lipid and glucose concentrations, body weight, and blood pressure: Systematic review and meta-analysis. American Journal Clinical Nutrition, 88, 1167-75.

Surjushe, A., Vasani, R., \& Saple, D. G., (2008). Aloe vera: A short review. Indian Journal of Dermatology, 53 (4), 163-166.

Yagi, A., Hegazy, S., Kabbash, A., \& Wahab, E. A. (2009). Possible hypoglycemic effect of Aloe Vera Linn High molecular weight fractions on type 2 diabetic patients. Saudi Pharmaceutical Journal, $\quad 17, \quad 209-215$. doi: $10.1016 /$ j.jsps.2009.08.007 